\title{
Methylobacterium phyllosphaerae sp. nov., a pink- pigmented, facultative methylotroph from the phyllosphere of rice
}

\author{
Munusamy Madhaiyan, ${ }^{1}$ Selvaraj Poonguzhali, ${ }^{1}$ Soon-Wo Kwon ${ }^{2}$ \\ and Tong-Min $\mathrm{Sa}^{1}$
}

Correspondence

Tong-Min Sa

tomsa@chungbuk.ac.kr
${ }^{1}$ Department of Agricultural Chemistry, Chungbuk National University, Cheongju, Chungbuk 361-
763 , Republic of Korea
${ }^{2}$ Korean Agricultural Culture Collection (KACC), Microbial Genetics Division, National Institute of
Agricultural Biotechnology, Rural Development Administration, Suwon 441-707, Republic of Korea

A pink-pigmented, aerobic, facultatively methylotrophic bacterial strain, $\mathrm{CBMB} 27^{\top}$, isolated from leaf tissues of rice (Oryza sativa L. 'Dong-Jin'), was analysed using a polyphasic taxonomic approach. Comparative 16S rRNA gene sequence-based phylogenetic analysis placed the strain in a clade with the species Methylobacterium oryzae, Methylobacterium fujisawaense and Methylobacterium mesophilicum; strain $\mathrm{CBMB}^{\top} 7^{\top}$ showed sequence similarities of $98.3,98.5$ and $97.3 \%$, respectively, to the type strains of these three species. DNA-DNA hybridization experiments revealed low levels $(<38 \%)$ of DNA-DNA relatedness between strain CBMB27 ${ }^{\top}$ and its closest relatives. The sequence of the 1-aminocyclopropane-1-carboxylate deaminase gene (acdS) in strain CBMB27 $7^{\top}$ differed from those of close relatives. The major fatty acid of the isolate was $\mathrm{C}_{18: 1} \omega 7 \mathrm{c}$ and the $\mathrm{G}+\mathrm{C}$ content of the genomic DNA was $66.8 \mathrm{~mol} \%$. Based on the results of $16 \mathrm{~S}$ rRNA gene sequence analysis, DNA-DNA hybridization, and physiological and biochemical characterization, which enabled the isolate to be differentiated from all recognized species of the genus Methylobacterium, it was concluded that strain CBMB27 ${ }^{\top}$ represents a novel species in the genus Methylobacterium for which the name Methylobacterium phyllosphaerae sp. nov. is proposed (type strain $\mathrm{CBMB}^{2} 7^{\top}=\mathrm{LMG} 24361^{\top}=\mathrm{KACC} 11716^{\top}$ $=$ DSM $19779^{\top}$ ).
Bacteria of the genus Methylobacterium, class Alphaproteobacteria, consist mainly of a group of pinkpigmented facultatively methylotrophic bacteria with the ability to utilize $\mathrm{C}_{1}$ compounds such as methanol or formaldehyde and other, multicarbon compounds (Green, 1992). Cells are strictly aerobic, Gram-negative rods and, at the time of writing, the genus Methylobacterium comprised 28 species with validly published names (http://www. bacterio.cict.fr $/ \mathrm{m} /$ methylobacterium.html), with Methylobacterium organophilum as the type species (Patt et al., 1976). Members of the genus Methylobacterium are versatile in nature and ubiquitous on plant surfaces, potentially dominating the phyllosphere population (Corpe \& Rheem, 1989). Their association with plants extends from free-living to epiphytic, endophytic and

Abbreviation: ACCD, 1-aminocyclopropane-1-carboxylate deaminase.

The GenBank/EMBL/DDBJ accession numbers for the 16S rRNA, $m \times a F$ and acdS gene sequences of strain $\mathrm{CBMB}^{\top} 7^{\top}$ are EF126746, EF562496 and EU430438, respectively.

API ZYM reactions of strain CBMB27 ${ }^{\top}$ and related strains are available as supplementary material with the online version of this paper. symbiotic (Pirttilä et al., 2000; Sy et al., 2001; Kutschera, 2007; Schauer \& Kutschera, 2008) and their presence has been detected by cultivation-independent methods (Araújo et al., 2002; Idris et al., 2004; Jackson et al., 2006). Interand intracellular colonization of plant tissues by Methylobacterium species and their mode of transmission from seed to aerial parts have been illustrated (Pirttilä et al., 2000; Sy et al., 2005; Poonguzhali et al., 2008).

Methylobacteria, as plant symbionts, utilize the methanol emitted from plants and, in turn, impart beneficial effects on plant growth through one or more mechanisms that include production of phytohormones like indoleacetic acid or cytokinins and vitamins (Basile et al., 1985; Koenig et al., 2002; Trotsenko et al., 2001), synthesis of enzymes such as urease or 1-aminocyclopropane-1-carboxylate deaminase (ACCD) that modulate plant growth (Holland \& Polacco, 1992; Madhaiyan et al., 2006, 2007b) and production of siderophores (Idris et al., 2004). Furthermore, they tolerate heavy metals and are able to reduce their phytotoxicity and improve plant growth (Idris et al., 2004; Madhaiyan et al., 2007a). The data presented in 
this paper include the formal taxonomic description of a novel species of the genus Methylobacterium, which was isolated from rice leaf tissues and produces ACCD.

Strain $\mathrm{CBMB}_{2} 7^{\mathrm{T}}$ was isolated from leaf tissues of rice (Oryza sativa L. 'Dong-Jin') collected from the National Honam Agricultural Experiment Station (Iksan, Republic of Korea) on selective ammonium mineral salts (AMS) medium (Whittenbury et al., 1970) supplemented with filter-sterilized cycloheximide $\left(10 \mu \mathrm{g} \mathrm{ml}^{-1}\right)$ and $0.5 \%$ $(\mathrm{v} / \mathrm{v})$ methanol at $28{ }^{\circ} \mathrm{C}$ by the leaf imprinting method (Chanprame et al., 1996). The strain was maintained on nutrient agar (NA; Difco) with $1 \%(\mathrm{v} / \mathrm{v})$ methanol or on AMS medium with $0.5 \%(\mathrm{v} / \mathrm{v})$ methanol. Morphological properties were studied according to standard protocols (Gerhardt et al., 1994). Nutritional characteristics were determined as described previously by using Biolog GN2 MicroPlates (Madhaiyan et al., 2007c) and utilization of carbon sources not included on the Biolog plates was determined as described by Green \& Bousfield (1982). Other physiological and biochemical characteristics were tested using the API ZYM, API 20NE and API 32GN galleries (bioMérieux) following the manufacturer's instructions. Methylobacterium oryzae $\mathrm{CBMB}^{\mathrm{T}}{ }^{\mathrm{T}}$ was included as a positive control for these experiments. Scanning electron microscope observations were performed on fixed material that was prepared for routine examination as described by Bozzola \& Russell (1998). Samples were critical-point-dried, mounted on stubs, sputter-coated with gold/palladium and visualized by using a Hitachi S-2500C scanning electron microscope with a GEMINI column equipped with a field-emission electron source. The presence of the enzyme ACCD was determined by plate and quantitative assays as described previously (Madhaiyan et al., 2006). Cells of strain $\mathrm{CBMB}_{2} 7^{\mathrm{T}}$ were Gram-negative, aerobic, non-endospore-forming rods that were frequently branched and occurred singly or in rosettes on solid AMS medium and formed pink- to red-pigmented colonies. A photomicrograph of strain $\mathrm{CBMB} 27^{\mathrm{T}}$ grown on the solid surface of AMS medium supplemented with $0.5 \%$ methanol is shown in Fig. 1. Strain $\mathrm{CBMB}_{2} 7^{\mathrm{T}}$ grew on $\mathrm{C}_{1}$

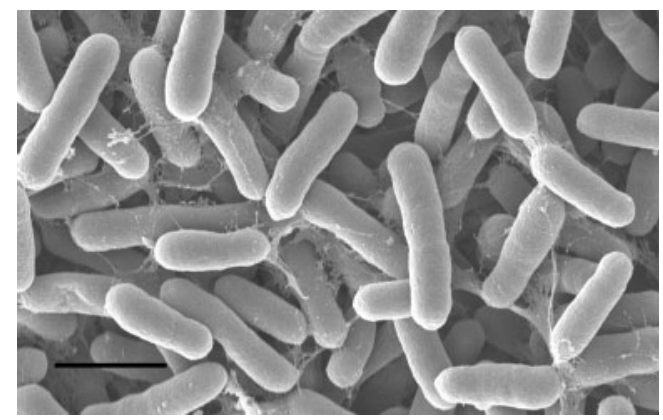

Fig. 1. Photomicrograph of cells of strain $\mathrm{CBMB}^{2} 7^{\top}$ on $\mathrm{AMS}$ medium supplemented with $0.5 \%(\mathrm{v} / \mathrm{v})$ methanol. Bar, $2 \mu \mathrm{m}$. substrates such as methanol, methylamine and formate, but not on dimethylamine, trimethylamine or formaldehyde; differential utilization of several carbon sources by the isolate and its closest relatives is summarized in Table 1. A summary of enzyme reactions of strain $\mathrm{CBMB} 27^{\mathrm{T}}$ compared with those of type strains of closely related Methylobacterium species is available as Supplementary Table S1 in IJSEM Online. Strain CBMB $27^{\mathrm{T}}$ also utilized 1aminocyclopropane 1-carboxylate as a nitrogen source when tested with a plate assay, and considerable ACCD activity could be detected in cell-free extracts.

The 16S rRNA gene was PCR-amplified from the DNA extracts by using universal primers 27F (5'-AGAGTTTGATCCTGGCTCAG- $3^{\prime}$ ) and 1492R (5'-GGTTACCTTGTTACGACTT-3') and the full gene sequence was determined by the fluorescent dye terminator method using a sequencing kit (ABI PRISM BigDye Terminator cycle sequencing ready reaction kit v. 3.1) and products were run on a ABI3730XL capillary DNA sequencer (ABI PRISM 310 Genetic Analyzer). The resultant 16S rRNA gene sequence was compared with available sequences from GenBank using the program BLAST (http://www.ncbi.nlm. nih.gov.proxy.lib.siu.edu/blast/) to determine an approximate phylogenetic affiliation and gene sequences were aligned with those of closely related strains using the software CLUSTAL W (Thompson et al., 1994). Phylogenetic trees were constructed by the neighbour-joining method with the program package MEGA 3.1 (Kumar et al., 2004). Bootstrap confidence values were obtained using 1000 resamplings. The methanol dehydrogenase gene $(m x a F)$, required for methanol utilization, and the acdS gene, which accounts for ACCD activity, were amplified from DNA extracts using primer pairs mxaF f1003 and mxaF r1561 (5'-GCGGCACCAACTGGGGCTGGT- $3^{\prime}$ and $5^{\prime}$-GGGCAGCATGAAGGGCTCCC-3', respectively) for $m \times a F$ and F1936 and F1939 (5'-GHGAMGACTGCAAYWSYGGC-3' and $5^{\prime}$-GARGCRTCGAYVCCRATCAC-3', respectively) for acdS (McDonald \& Murrell, 1997; Blaha et al., 2006). Products were sequenced directly and analysed as described by McDonald \& Murrell (1997) and Blaha et al. (2006).

Comparative 16S rRNA gene sequence analysis indicated that strain $\mathrm{CBMB} 27^{\mathrm{T}}$ was affiliated phylogenetically to the genus Methylobacterium, forming a phyletic lineage within it with $M$. oryzae $\mathrm{CBMB}_{20}^{\mathrm{T}}$ (bootstrap value of $54 \%$ ). Sequence similarity calculations and phylogenetic analysis revealed that strain $\mathrm{CBMB} 27^{\mathrm{T}}$ was closely related to $M$. oryzae $\mathrm{CBMB}^{2} 0^{\mathrm{T}}$, M. fujisawaense DSM $5686^{\mathrm{T}}, M$. mesophilicum DSM $1708^{\mathrm{T}}$ and M. radiotolerans JCM $2831^{\mathrm{T}}$, with sequence similarities of $98.3,98.5,97.3$ and $96.8 \%$, respectively (Fig. 2). Sequencing of the $m x a F$ gene from $\mathrm{CBMB} 27^{\mathrm{T}}$ resulted in a continuous stretch of $556 \mathrm{bp}$ and, when compared with representative Methylobacterium species, revealed $99.3 \%$ gene sequence similarity with sequences from the type strains of $M$. oryzae and $M$. fujisawaense. The acdS gene sequence of $\mathrm{CBMB} 27^{\mathrm{T}}$ was closely related to those of the type strains of $M$. oryzae (98.1\% similarity) and M. fujisawaense $(92.5 \%)$. The 
Table 1. Differential carbon source utilization of strain $\mathrm{CBMB} 27^{\top}$ and related Methylobacterium species

Utilization of various compounds as sole sources of carbon and energy is shown. Adapted from Green (1992). Species/strains: 1, strain CBMB27 ${ }^{\mathrm{T}}$ (M. phyllosphaerae sp. nov.); 2, M. oryzae (Madhaiyan et al., 2007c); 3, M. fujisawaense (Kouno \& Ozaki, 1975); 4, M. mesophilicum (Austin \& Goodfellow, 1979); 5, M. radiotolerans (Ito \& Iizuka, 1971); 6, M. extorquens (Urakami \& Komagata, 1984); 7, M. adhaesivum (Gallego et al., 2006); 8, M. suomiense (Doronina et al., 2002); 9, M. organophilum (Patt et al., 1976); 10, M. rhodesianum (Rock et al., 1976); 11, M. zatmanii (Rock et al., 1976); 12, M. rhodinum (Heumann, 1962); 13, M. nodulans (Jourand et al., 2004); 14, M. hispanicum (Gallego et al., 2005); 15, M. populi (Van Aken et al., 2004). +, Growth; -, no growth; v, variable; w, weak growth; NA, no data available. All species are positive for growth on methanol.

\begin{tabular}{|c|c|c|c|c|c|c|c|c|c|c|c|c|c|c|c|}
\hline Carbon source & 1 & 2 & 3 & 4 & 5 & 6 & 7 & 8 & 9 & 10 & 11 & 12 & 13 & 14 & 15 \\
\hline D-Glucose & W & - & + & + & + & - & - & + & - & - & - & + & - & - & - \\
\hline Fucose & + & - & + & + & + & - & - & NA & - & - & - & - & - & - & - \\
\hline D-Xylose & + & - & + & + & + & - & - & - & - & - & - & + & + & - & - \\
\hline L-Arabinose & + & + & + & + & + & - & - & - & - & - & - & - & + & - & - \\
\hline Fructose & + & - & - & - & - & - & + & + & + & + & + & + & - & - & + \\
\hline L-Glutamate & + & + & + & + & + & + & + & - & + & - & - & + & + & + & - \\
\hline Citrate & + & - & + & + & + & - & + & - & - & - & - & + & + & + & - \\
\hline Sebacate & + & + & + & $\mathrm{V}$ & + & - & NA & NA & - & - & - & - & NA & NA & - \\
\hline Acetate & $\mathrm{W}$ & - & + & - & + & + & + & + & + & + & + & + & + & + & + \\
\hline Betaine & - & - & - & - & + & + & NA & + & - & + & - & + & + & NA & + \\
\hline Tartrate & - & - & V & - & - & V & NA & - & - & - & v & - & + & NA & + \\
\hline Ethanol & $\mathrm{w}$ & $\mathrm{w}$ & + & + & V & + & NA & + & + & + & + & + & + & NA & + \\
\hline Methane & - & - & - & - & - & - & NA & - & $\mathrm{V}$ & - & - & - & $\mathrm{NA}$ & NA & + \\
\hline Methylamine & $\mathrm{w}$ & - & - & - & - & + & NA & + & + & + & + & + & - & NA & + \\
\hline Dimethylamine & - & - & - & - & - & - & NA & - & - & + & - & - & NA & NA & - \\
\hline Trimethylamine & - & - & - & - & - & - & $\mathrm{NA}$ & - & + & - & - & - & NA & $\mathrm{NA}$ & - \\
\hline Nutrient agar & + & + & + & - & + & + & NA & - & + & + & + & + & NA & $\mathrm{NA}$ & + \\
\hline
\end{tabular}

presence of ACCD in Methylobacterium and various bacterial genera has been reported (Madhaiyan et al., 2006; Penrose \& Glick, 2001; Belimov et al., 2001).
For cellular fatty acid analysis, the strain was cultured in NA with $1 \%(\mathrm{v} / \mathrm{v})$ methanol at $28{ }^{\circ} \mathrm{C}$ for $48 \mathrm{~h}$. Fatty acids were extracted, derivatized to methyl esters and analysed by

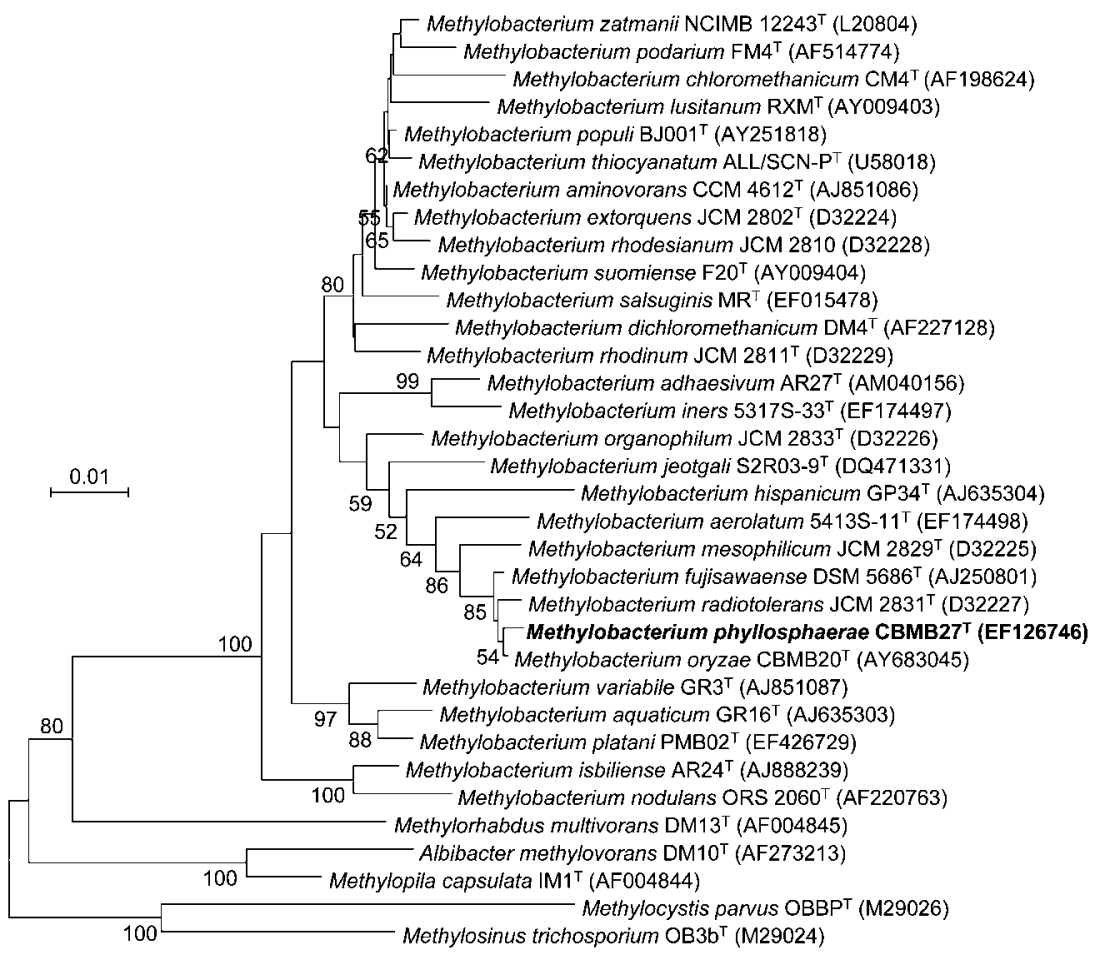

Fig. 2. Phylogenetic tree based on $16 \mathrm{~S}$ rRNA gene sequence comparison showing the position of strain $\mathrm{CBMB}^{\mathrm{T}} 7^{\top}$ and related species of the genus Methylobacterium. Numbers at nodes indicate levels of bootstrap support based on a neighbour-joining analysis of 1000 resampled datasets (only values greater than $50 \%$ are shown). Bar, 0.01 substitutions per site. 
GC (Hewlett Packard 6890) using the Microbial Identification System (MIDI; Microbial ID) software package, according to the standard protocol (Sasser, 1990). The G + C content of genomic DNA was determined by HPLC analysis of individual nucleosides using a reversed-phase column (Supelcosil LC-18-S; Supelco) as described by Mesbah et al. (1989). DNA-DNA hybridization was carried out to determine the relatedness between strain $\mathrm{CBMB} 27^{\mathrm{T}}$ and its closest relatives according to the filter hybridization method (Seldin \& Dubnau, 1985). Probe labelling was conducted by using the non-radioactive DIG-High Prime system (Roche Diagnostics) and hybridized DNA was visualized using the DIG luminescent detection kit (Roche Diagnostics). Hybridization temperatures were 60 and $65{ }^{\circ} \mathrm{C}$ and DNA-DNA relatedness was quantified by using a densitometer (Bio-Rad). The fatty acid profile of strain $\mathrm{CBMB} 27^{\mathrm{T}}$ consisted mainly of cisvaccenic acid $\left(\mathrm{C}_{18: 1} \omega 7 c\right)$, iso- $\mathrm{C}_{17: 0} 3-\mathrm{OH}$ and octadecanoic (stearic) acid $\left(\mathrm{C}_{18: 0}\right)$ (summarized in Table 2$)$. The DNA G $+\mathrm{C}$ content of strain $\mathrm{CBMB} 27^{\mathrm{T}}$ was $66.8 \mathrm{~mol} \%$, which falls within the range described for the genus Methylobacterium (Green, 1992). Strain $\mathrm{CBMB}^{\mathrm{T}} \mathrm{T}^{\mathrm{T}}$ showed low levels of DNA-DNA relatedness with its closest relatives, $M$. fujisawaense KACC $10744^{\mathrm{T}}(37.6 \%)$, $M$. mesophilicum DSM $1708^{\mathrm{T}}(31.5 \%), \quad$. radiotolerans DSM $1819^{\mathrm{T}}(31.8 \%)$, M. adhaesivum KACC $12195^{\mathrm{T}}$ $(23.2 \%), M$. extorquens KACC $11434^{\mathrm{T}}(13.8 \%)$ and $M$. oryzae KACC $11585^{\mathrm{T}}(8.06 \%)$. These results indicate that strain $\mathrm{CBMB} 27^{\mathrm{T}}$ does not belong to any of the above species when the recommendation of a threshold value of $70 \%$ DNA-DNA relatedness for species definition is considered (Wayne et al., 1987).
The $16 \mathrm{~S}$ rRNA sequence similarity data, DNA-DNA hybridization values and other phenotypic characteristics allow strain $\mathrm{CBMB} 27^{\mathrm{T}}$ to be distinguished from other members of the genus Methylobacterium. On the basis of these results, strain $\mathrm{CBMB} 27^{\mathrm{T}}$ is considered to represent a novel species of Methylobacterium, for which the name Methylobacterium phyllosphaerae sp. nov. is proposed.

\section{Description of Methylobacterium phyllosphaerae sp. nov.}

Methylobacterium phyllosphaerae (phyl.lo.sphae' rae. N.L. n. phyllosphaera phyllosphere; N.L. gen. n. phyllosphaerae of the phyllosphere).

Gram-negative, non-endospore-forming, strictly aerobic, motile rods $(0.63-0.64 \times 1.8-2.7 \mu \mathrm{m})$ occurring singly, in pairs or in rosettes. Colonies are pink to red, convex, translucent with regular edges, slow-growing and 0.2$0.8 \mathrm{~mm}$ in diameter after $96 \mathrm{~h}$ at $28{ }^{\circ} \mathrm{C}$ on AMS. Grows on NA, R2A, peptone-yeast extract-glucose, succinate, glycerol-peptone and plate count agar media. Does not grow in the presence of $\geqslant 2.0 \% \mathrm{NaCl}$. Growth occurs at 20 $30{ }^{\circ} \mathrm{C}$ (optimal temperature $28{ }^{\circ} \mathrm{C}$ ) and $\mathrm{pH}$ 5.0-9.0 (optimal pH 6.8). The pink pigment is water-insoluble and has absorption maxima at 233, 359, 505 and $545 \mathrm{~nm}$ in chloroform/methanol $(1: 1)$. Catalase, oxidase, arginine dihydrolase and urease tests are positive. Pectinase, cellulase, protease and $\beta$-galactosidase are absent. Tests for nitrate reduction, glucose fermentation, indole production and methyl red and Voges-Proskauer tests are negative. Gelatin, starch, glycerol tributyrate, casein and aesculin are not hydrolysed. Hydrogen sulfide is not

Table 2. Cellular fatty acid compositions of strain $C B M B 27^{\top}$ and the type strains of related species of the genus Methylobacterium

Strains: 1, CBMB27 $7^{\mathrm{T}} ; 2$, M. oryzae CBMB20 ${ }^{\mathrm{T}} ; 3$, M. fujisawaense KACC $10744^{\mathrm{T}} ; 4$, M. mesophilicum DSM $1708^{\mathrm{T}} ; 5$, M. radiotolerans DSM $1819^{\mathrm{T}}$; 6 , M. extorquens DSM $1337^{\mathrm{T}}$; 7, M. adhaesivum KACC $12195^{\mathrm{T}}$; 8, M. hispanicum DSM $16372^{\mathrm{T}}$; 9, M. organophilum DSM $760^{\mathrm{T}}$; 10 , M. iners KACC $11765^{\mathrm{T}}$; 11, M. aerolatum KACC $11766^{\mathrm{T}}$; 12, M. platani KCTC $12901^{\mathrm{T}}$. Data from this study (strains 1-9), Weon et al. (2008) and Kang et al. (2007). Values are percentages of total fatty acids; -, not detected. ECL, Equivalent chain-length. Fatty acids representing less than $0.3 \%$ in all strains were omitted.

\begin{tabular}{|c|c|c|c|c|c|c|c|c|c|c|c|c|}
\hline Fatty acid & 1 & 2 & 3 & 4 & 5 & 6 & 7 & 8 & 9 & 10 & 11 & 12 \\
\hline $\mathrm{C}_{12: 0}$ & - & - & - & - & - & - & - & 4.5 & - & 0.8 & - & - \\
\hline $\mathrm{C}_{16: 0}$ & 4.1 & 3.0 & 2.0 & 3.2 & 3.0 & 2.6 & 4.5 & 4.6 & 3.0 & 3.3 & 3.9 & 7.6 \\
\hline iso- $\mathrm{C}_{17: 0} 3-\mathrm{OH}$ & 11.5 & - & - & - & - & 9.1 & - & - & - & - & - & - \\
\hline $\mathrm{C}_{18: 0}$ & 4.4 & 4.6 & 5.4 & 4.1 & 5.3 & 2.3 & - & 4.6 & 6.3 & 2.9 & 2.4 & 1.7 \\
\hline $\mathrm{C}_{18: 1} \omega 7 c$ & 75.1 & 88.2 & 88.7 & 88.6 & 88.8 & 64.8 & 79.3 & 68.5 & 88.1 & 82.3 & 82.6 & 81.0 \\
\hline Summed feature $2^{*}$ & 2.7 & 0.8 & 0.8 & 1.06 & 0.8 & 6.3 & 2.2 & 8.0 & 0.8 & 2.2 & 3.50 & 2.0 \\
\hline Summed feature $3^{*}$ & 1.1 & 1.8 & 1.7 & 0.8 & 0.8 & 12.6 & 8.5 & 6.3 & 0.7 & 6.5 & 6.0 & 2.2 \\
\hline Summed feature $4^{\star}$ & - & - & - & - & - & 1.31 & 5.1 & - & - & - & - & - \\
\hline Unknown ECL 14.959 & - & 0.4 & 0.5 & 0.5 & 0.5 & - & - & - & 0.5 & - & - & - \\
\hline
\end{tabular}

${ }^{*}$ Summed features represent groups of two or three fatty acids that could not be separated by GLC with the MIDI system. Summed feature 2 contained iso- $\mathrm{C}_{16: 1} \mathrm{I}$ and/or $\mathrm{C}_{14: 0} 3-\mathrm{OH}$; summed feature 3 contained $\mathrm{C}_{16: 1} \omega 7 c$ and/or iso- $\mathrm{C}_{15: 0} 2-\mathrm{OH}$; summed feature 4 contained iso- $\mathrm{C}_{17: 1} \mathrm{I}$ and/or anteiso- $\mathrm{C}_{17: 0} \mathrm{~B}$. 
produced. Simmons' citrate test is positive. D-Glucose, fucose, D-xylose, L-arabinose, fructose, L-glutamate, citrate, sebacate, acetate, ethanol, methylamine and methanol are utilized as sole carbon sources. Ammonium sulfate, potassium nitrate, sodium nitrate, ammonium chloride, L-alanine, L-glutamate, L-glutamine, urea, methylamine, trimethylamine, 1-aminocyclopropane 1-carboxylate and potassium thiocyanate are utilized as sole nitrogen sources. The type strain is highly resistant (up to $500 \mu \mathrm{g} \mathrm{ml}^{-1}$ ) to ampicillin, carbenicillin, nalidixic acid and chloramphenicol, but sensitive (lowest concentration) to kanamycin $\left(15 \mu \mathrm{g} \mathrm{ml}^{-1}\right)$, gentamicin $\left(200 \mu \mathrm{g} \mathrm{ml}^{-1}\right)$, spectinomycin $\left(200 \mu \mathrm{g} \mathrm{ml}^{-1}\right)$ and tetracycline $\left(100 \mu \mathrm{g} \mathrm{ml}^{-1}\right)$. The following compounds are utilized as sole carbon and energy sources (Biolog): Tween 80, L-arabinose, D-fructose, Lfucose, gentiobiose, pyruvic acid methyl ester, succinic acid monomethyl ester, cis-aconitic acid, citric acid, formic acid, D-galactonic acid lactone, D-galacturonic acid, Dgluconic acid, D-glucosaminic acid, $\alpha$-, $\beta$ - and $\gamma$-hydroxybutyric acids, $\alpha$-ketobutyric acid, $\alpha$-ketoglutaric acid, $\alpha$ ketovaleric acid, DL-lactic acid, propionic acid, D-saccharic acid, succinic acid, bromosuccinic acid, succinamic acid, Lalaninamide, L-alanyl glycine, L-asparagine, L-aspartic acid, L-glutamic acid, L-pyroglutamic acid, L-serine, 2-aminoethanol and glycerol. The following carbon sources are utilized in API 20NE and API 32GN tests: D-glucose, Larabinose, potassium gluconate, adipic acid, malic acid, Lrhamnose, D-ribose, inositol, sucrose, itaconic acid, sodium malonate, lactic acid, L-alanine, potassium 5-ketogluconate, glycogen, 3-hydroxybenzoic acid, L-serine, salicin, melibiose, L-fucose, D-sorbitol, L-arabinose, potassium 2ketogluconate, 3-hydroxybutyric acid, 4-hydroxybenzoic acid and L-proline. In API ZYM assays, esterase (C4), esterase lipase (C8), leucine arylamidase, trypsin, acid phosphatase and naphthol-AS-BI-phosphohydrolase are present, but alkaline phosphatase, lipase (C14), valine arylamidase, cystine arylamidase, $\alpha$-chymotrypsin, $\alpha$-galactosidase, $\beta$-galactosidase, $\beta$-glucuronidase, $\alpha$-glucosidase, $\beta$-glucosidase, $N$-acetyl- $\beta$-glucosaminidase, $\alpha$-mannosidase and $\alpha$-fucosidase are absent. Cellular fatty acids identified in the type strain are $\mathrm{C}_{18: 1} \omega 7 c$, iso- $\mathrm{C}_{17: 0} 3-\mathrm{OH}, \mathrm{C}_{16: 0}$, $\mathrm{C}_{18: 0}$ and $\mathrm{C}_{18: 0} 3-\mathrm{OH}$.

The type strain is $\mathrm{CBMB} 27^{\mathrm{T}}$ (=LMG $24361^{\mathrm{T}}=\mathrm{KACC}$ $11716^{\mathrm{T}}=$ DSM $\left.19779^{\mathrm{T}}\right)$, isolated from the leaf surface of rice (Oryza sativa L. 'Dong-Jin'). The DNA G + C content of the type strain is $66.8 \mathrm{~mol} \%$.

\section{Acknowledgements}

M. M. is indebted to BrainKorea21, Republic of Korea, for a position as invited scientist. The authors also acknowledge support from the Rural Development Administration, Republic of Korea.

\section{References}

Araújo, W. L., Marcon, J., Maccheroni, W., Jr, Van Elsas, J. D., Van Vuurde, J. W. \& Azevedo, J. L. (2002). Diversity of endophytic bacterial populations and their interaction with Xylella fastidiosa in citrus plants. Appl Environ Microbiol 68, 4906-4914.

Austin, B. \& Goodfellow, M. (1979). Pseudomonas mesophilica, a new species of pink bacteria isolated from leaf surfaces. Int J Syst Bacteriol 29, 373-378.

Basile, D. V., Basile, M. R., Li, Q.-Y. \& Corpe, W. A. (1985). Vitamin $\mathrm{B}_{12}$-stimulated growth and development of Jungermannia leiantha Grolle and Gymnocolea inflata (Huds.) Dum. (Hepaticae). Bryologist 88, 77-81.

Belimov, A. A., Safronova, V. I., Sergeyeva, T. A., Egorova, T. N., Matveyeva, V. A., Tsyganov, V. E., Borisov, A. Y., Tikhonovich, I. A., Kluge, C. \& other authors (2001). Characterization of plant growth promoting rhizobacteria isolated from polluted soils and containing 1-aminocyclopropane-1-carboxylate deaminase. Can J Microbiol 47, 642-652.

Blaha, D., Prigent-Combaret, C., Sajjad Mirza, M. \& Moënne-Loccoz, Y. (2006). Phylogeny of the 1-aminocyclopropane-1-carboxylic acid deaminase-encoding gene acdS in phytobeneficial and pathogenic proteobacteria and relation with strain biogeography. FEMS Microbiol Ecol 56, 455-470.

Bozzola, J. J. \& Russell, L. D. (1998). Electron Microscopy, 2nd edn. Sudbury, MA: Jones \& Bartlett.

Chanprame, S., Todd, J. J. \& Widholm, J. M. (1996). Prevention of pinkpigmented methylotrophic bacteria (Methylobacterium mesophilicum) contamination of plant tissue cultures. Plant Cell Rep 16, 222-225.

Corpe, W. A. \& Rheem, S. (1989). Ecology of the methylotrophic bacteria on living leaf surfaces. FEMS Microbiol Ecol 62, 243-250.

Doronina, N. V., Trotsenko, Y. A., Kuznetsov, B. B., Tourova, T. P. \& Salkinoja-Salonen, M. S. (2002). Methylobacterium suomiense sp. nov. and Methylobacterium lusitanum sp. nov., aerobic, pinkpigmented, facultatively methylotrophic bacteria. Int J Syst Evol Microbiol 52, 773-776.

Gallego, V., García, M. T. \& Ventosa, A. (2005). Methylobacterium variabile sp. nov., a methylotrophic bacterium isolated from an aquatic environment. Int J Syst Evol Microbiol 55, 1429-1433.

Gallego, V., García, M. T. \& Ventosa, A. (2006). Methylobacterium adhaesivum sp. nov., a methylotrophic bacterium isolated from drinking water. Int J Syst Evol Microbiol 56, 339-342.

Gerhardt, P., Murray, R. G. E., Wood, W. A. \& Krieg, N. R. (editors) (1994). Methods for General and Molecular Bacteriology. Washington, DC: American Society for Microbiology.

Green, P. N. (1992). The genus Methylobacterium. In The Prokaryotes, 2nd edn, pp. 2342-2349. Edited by A. Balows, H. G. Trüper, M. Dworkin, W. Harder \& K. H. Schleifer. New York: Springer.

Green, P. N. \& Bousfield, I. J. (1982). A taxonomic study of some Gram-negative facultatively methylotrophic bacteria. J Gen Microbiol 128, 623-638.

Heumann, W. (1962). Die Methodik der Kreuzung sternbildender Bakterien. Biol Zentralbl 81, 341-354 (in German).

Holland, M. A. \& Polacco, J. C. (1992). Urease-null and hydrogenasenull phenotypes of a phylloplane bacterium reveal altered nickel metabolism in two soybean mutants. Plant Physiol 98, 942-948.

Idris, R., Trifonova, R., Puschenreiter, M., Wenzel, W. W. \& Sessitsch, A. (2004). Bacterial communities associated with flowering plants of the Ni hyperaccumulator Thlaspi goesingense. Appl Environ Microbiol 70, 2667-2677.

Ito, H. \& lizuka, H. (1971). Taxonomic studies on a radio-resistant Pseudomonas. XII. Studies on the microorganisms of cereal grain. Agric Biol Chem 35, 1566-1571.

Jackson, E. F., Echlin, H. L. \& Jackson, C. R. (2006). Changes in the phyllosphere community of the resurrection fern, Polypodium 
polypodioides, associated with rainfall and wetting. FEMS Microbiol Ecol 58, 236-246.

Jourand, P., Giraud, E., Béna, G., Sy, A., Willems, A., Gillis, M., Dreyfus, B. \& de Lajudie, P. (2004). Methylobacterium nodulans $\mathrm{sp.}$ nov., for a group of aerobic, facultatively methylotrophic, legume root-nodule-forming and nitrogen-fixing bacteria. Int J Syst Evol Microbiol 54, 2269-2273.

Kang, Y. S., Kim, J., Shin, H. D., Nam, Y. D., Bae, J. W., Jeon, C. O. \& Park, W. (2007). Methylobacterium platani sp. nov., isolated from a leaf of the tree Platanus orientalis. Int J Syst Evol Microbiol 57, 2849 2853.

Koenig, R. L., Morris, R. O. \& Polacco, J. C. (2002). tRNA is the source of low-level trans-zeatin production in Methylobacterium spp. J Bacteriol 184, 1832-1842.

Kouno, K. \& Ozaki, A. (1975). Distribution of methanol-utilizing bacteria. In Proceedings of the International Symposium on Microbial Growth on $C_{1}$ Compounds, pp. 11-21. Osaka, Japan: Society of Fermentation Technology.

Kumar, S., Tamura, K. \& Nei, M. (2004). MEGA3: integrated software for molecular evolutionary genetics analysis and sequence alignment. Brief Bioinform 5, 150-163.

Kutschera, U. (2007). Plant-associated methylobacteria as co-evolved phytosymbionts: a hypothesis. Plant Signal Behav 2, 74-78.

Madhaiyan, M., Poonguzhali, S., Ryu, J.-H. \& Sa, T.-M. (2006). Regulation of ethylene levels in canola (Brassica campestris) by 1aminocyclopropane-1-carboxylate deaminase-containing Methylobacterium fujisawaense. Planta 224, 268-278.

Madhaiyan, M., Poonguzhali, S. \& Sa, T. M. (2007a). Metal tolerating methylotrophic bacteria reduces nickel and cadmium toxicity and promotes plant growth of tomato (Lycopersicon esculentum L.). Chemosphere 69, 220-228.

Madhaiyan, M., Poonguzhali, S. \& Sa, T. M. (2007b). Characterization of 1-aminocyclopropane-1-carboxylate (ACC) deaminase containing Methylobacterium oryzae and interactions with auxins and ACC regulation of ethylene in canola (Brassica campestris). Planta 226, 867-876.

Madhaiyan, M., Kim, B.-Y., Poonguzhali, S., Kwon, S.-W., Song, M.-H., Ryu, J.-H., Go, S.-J., Koo, B.-S. \& Sa, T.-M. (2007c). Methylobacterium oryzae sp. nov., an aerobic, pink-pigmented, facultatively methylotrophic, 1-aminocyclopropane-1-carboxylate deaminase-producing bacterium isolated from rice. Int J Syst Evol Microbiol 57, 326-331.

McDonald, I. R. \& Murrell, J. C. (1997). The methanol dehydrogenase structural gene $m x a F$ and its use as a functional gene probe for methanotrophs and methylotrophs. Appl Environ Microbiol 63, 32183224.

Mesbah, M., Premachandran, U. \& Whitman, W. B. (1989). Precise measurement of the $\mathrm{G}+\mathrm{C}$ content of deoxyribonucleic acid by highperformance liquid chromatography. Int J Syst Bacteriol 39, 159-167.

Patt, T. E., Cole, G. C. \& Hanson, R. S. (1976). Methylobacterium, a new genus of facultatively methylotrophic bacteria. Int J Syst Bacteriol 26, 226-229.

Penrose, D. M. \& Glick, B. R. (2001). Levels of ACC and related compounds in exudate and extracts of canola seeds treated with ACC deaminase-containing plant growth-promoting bacteria. Can J Microbiol 47, 368-372.
Pirttilä, A. M., Laukkanen, H., Pospiech, H., Myllylä, R. \& Hohtola, A. (2000). Detection of intracellular bacteria in the buds of Scotch pine (Pinus sylvestris L.) by in situ hybridization. Appl Environ Microbiol 66, 3073-3077.

Poonguzhali, S., Madhaiyan, M., Yim, W.-J., Kim, K.-A. \& Sa, T.-M. (2008). Colonization pattern of plant root and leaf surfaces visualized by use of green-fluorescent-marked strain of Methylobacterium suomiense and its persistence in rhizosphere. Appl Microbiol Biotechnol 78, 1033-1043.

Rock, J. S., Goldberg, I., Ben-Bassat, A. \& Mateles, R. I. (1976). Isolation and characterization of two methanol-utilizing bacteria. Agric Biol Chem 40, 2129-2135.

Sasser, M. (1990). Identification of bacteria through fatty acid analysis. In Methods in Phytobacteriology, pp. 199-204. Edited by Z. Klement, K. Rudolph \& D. C. Sands. Budapest: Akademiai Kiado.

Schauer, S. \& Kutschera, U. (2008). Methylotrophic bacteria on the surfaces of field-grown sunflower plants: a biogeographic perspective. Theory Biosci 127, 23-29.

Seldin, L. \& Dubnau, D. (1985). Deoxyribonucleic acid homology among Bacillus polymyxa, Bacillus macerans, Bacillus azotofixans, and other nitrogen-fixing Bacillus strains. Int J Syst Bacteriol 35, 151-154.

Sy, A., Giraud, E., Jourand, P., Garcia, N., Willems, A., de Lajudie, P., Prin, Y., Neyra, M., Gillis, M. \& other authors (2001). Methylotrophic Methylobacterium bacteria nodulate and fix nitrogen in symbiosis with legumes. J Bacteriol 183, 214-220.

Sy, A., Timmers, A. C. J., Knief, C. \& Vorholt, J. A. (2005). Methylotrophic metabolism is advantageous for Methylobacterium extorquens during colonization of Medicago truncatula under competitive conditions. Appl Environ Microbiol 71, 7245-7252.

Thompson, J. D., Higgins, D. G. \& Gibson, T. J. (1994). Clustal w: improving the sensitivity of progressive multiple sequence alignment through sequence weighting, position-specific gap penalties and weight matrix choice. Nucleic Acids Res 22, 4673-4680.

Trotsenko, Y. A., Ivanova, E. G. \& Doronina, N. V. (2001). Aerobic methylotrophic bacteria as phytosymbionts. Mikrobiologiia 70, 725736 (in Russian).

Urakami, T. \& Komagata, K. (1984). Protomonas, a new genus of facultatively methylotrophic bacteria. Int J Syst Bacteriol 34, 188-201.

Van Aken, B., Peres, C. M., Lafferty Doty, S., Yoon, J. M. \& Schnoor, J. L. (2004). Methylobacterium populi sp. nov., a novel aerobic, pinkpigmented, facultatively methylotrophic, methane-utilizing bacterium isolated from poplar trees (Populus deltoides $\times$ nigra DN34). Int J Syst Evol Microbiol 54, 1191-1196.

Wayne, L. G., Brenner, D. J., Colwell, R. R., Grimont, P. A. D., Kandler, O., Krichevsky, M. I., Moore, L. H., Moore, W. E. C., Murray, R. G. E. \& other authors (1987). International Committee on Systematic Bacteriology. Report of the ad hoc committee on reconciliation of approaches to bacterial systematics. Int J Syst Bacteriol 37, 463-464.

Weon, H.-Y., Kim, B.-Y., Joa, J.-H., Son, J.-A., Song, M.-H., Kwon, S.-W., Go, S.-J. \& Yoon, S.-H. (2008). Methylobacterium iners sp. nov. and Methylobacterium aerolatum sp. nov., isolated from air samples in Korea. Int J Syst Evol Microbiol 58, 93-96.

Whittenbury, R., Phillips, K. C. \& Wilkinson, J. F. (1970). Enrichment, isolation and some properties of methane-utilizing bacteria. J Gen Microbiol 61, 205-218. 